\title{
A rare case of Meigs syndrome in pregnancy with bilateral ovarian masses
}

\author{
Veena Gupta, Nidhi Sachan*
}

Department of Obstetrics and Gynaecology, Moti Lal Nehru Medical College, Allahabad, Uttar Pradesh, India

Received: 22 September 2016

Accepted: 18 October 2016

\section{*Correspondence:}

Dr. Nidhi Sachan,

E-mail: sachannidhi05@gmail.com

Copyright: (C) the author(s), publisher and licensee Medip Academy. This is an open-access article distributed under the terms of the Creative Commons Attribution Non-Commercial License, which permits unrestricted non-commercial use, distribution, and reproduction in any medium, provided the original work is properly cited.

\begin{abstract}
Meig's syndrome is defined as the triad of ascitis, pleural effusion, along with benign ovarian tumour. Ovarian fibroma represents approximately $2-5 \%$ of the surgically removed ovarian tumours and Meig's syndrome occurs in only $1-2 \%$ of these cases, thus contributing to its rare occurrence. Here we report an unusual case of pregnancy with Meig's syndrome with ovarian fibroma on one side and large serous cystadenoma on other side. We present this case to emphasize the importance of this rare entity while dealing with any case of ascites.
\end{abstract}

Keywords: Ascites, Fibroma, Meigs

\section{INTRODUCTION}

Meigs syndrome is the triad of ascites, pleural effusion, and benign ovarian tumour (fibroma, fibrothecoma, brenner tumour and occasionally granulosa cell tumour) which resolves after resection of the tumour. ${ }^{1}$ It is a diagnosis of exclusion, only after ovarian carcinoma is ruled out.

\section{CASE REPORT}

25 years old primi patient presented to us with the complaints of amenorrhea 8.5 months and swelling all over body and breathlessness. On examination, patient had mild pallor, pulse 96/min, BP $130 / 80 \mathrm{~mm}$ of $\mathrm{Hg}$. Respiratory rate was $22 / \mathrm{min}$ with b/l basal crepts. Abdomen was distended with tense ascites, fluid thrill present. Fundal height could not be assessed. On per vaginal examination OS was closed. This was her first visit to our hospital with no previous investigations. A complete blood count ( $\mathrm{Hb}, \mathrm{PCV}$, platelet count), blood urea, serum creatinine, serum bilirubin, AST and ALT, blood sugar, serum protein and ECG of the patient was done and all the investigations were within normal limits with $\mathrm{Hb}$ of $8.2 \mathrm{gm} \%$. Ascitic tap was done which was transudative in nature. USG revealed a 36 week live fetus with EFW of $2.4 \mathrm{~kg}$ and a heterogeneous lesion of size $15.4 * 6.7 \mathrm{~cm}$ seen in lateral wall of uterus with gross ascitis. Emergency caeserian section of the patient was taken for fetal distress. About 2 litre of ascitic fluid was drained from abdominal cavity. A healthy baby of wt 2.7 $\mathrm{kg}$ delivered out. On inspection of ovaries, a $7 * 7 * \mathrm{~cm}$ of solid ovarian mass was present on right side and $16^{*} 17$ $\mathrm{cm}$ of solid cystic mass identified on left side. No normal ovarian tissue delineated.

Total abdominal hysterectomy with b/l salpingooophorectomy was done. One unit of blood was transfused intraoperative. The postoperative period was uneventful and patient was discharged on $8^{\text {th }}$ postoperative day. On her follow up visit on $15^{\text {th }}$ day, the patient was healthy with no recurrence of ascitis. HPE report of the specimen revealed fibrothecoma on right side and mucinous cystadenoma on left side. 


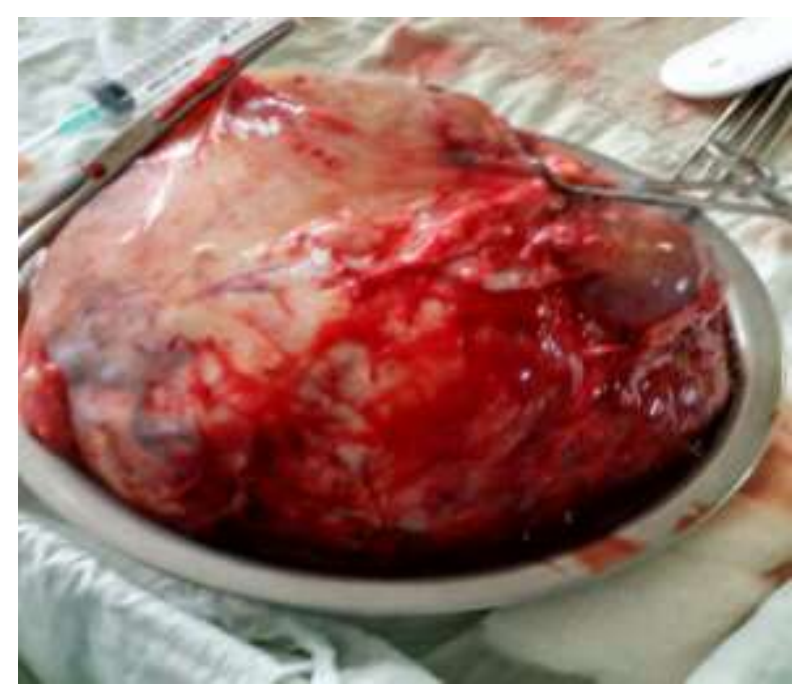

Figure 1: Left sided mass of $16 * 17 \mathrm{~cm}$ detected at the time of caeserian section.

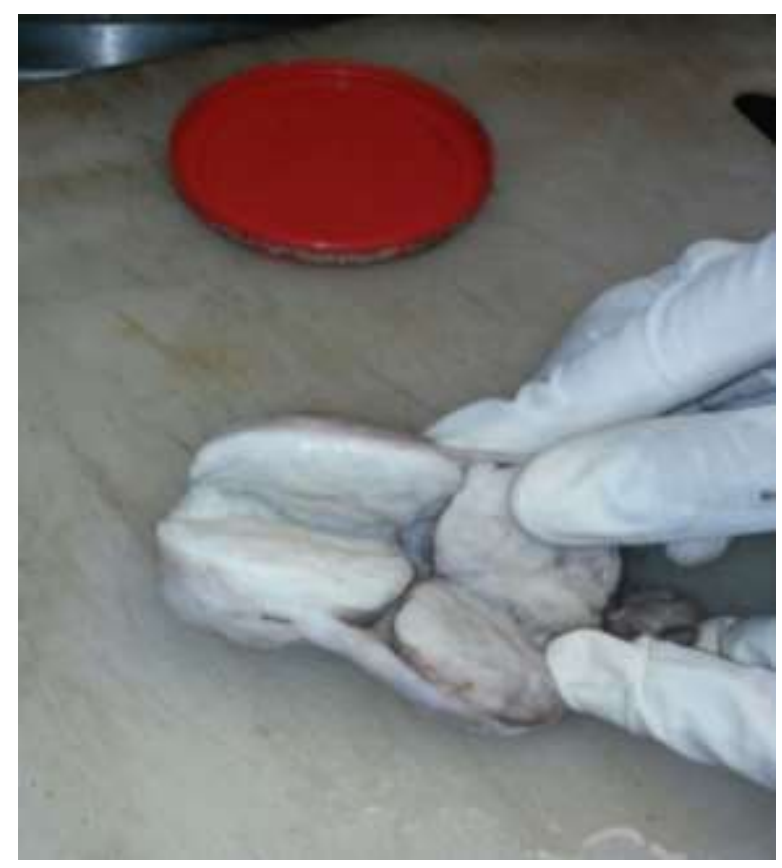

Figure 2: Cut section of right sided mass, a fibrothecoma, confirmed on HPE.

\section{DISCUSSION}

Meigs syndrome is a rare cause of ascitis, and its occurrence in pregnancy is even rarer. In our case, after all the investigations to find the cause of ascitis were normal, we found the cause after patient was taken for caeserian section. Ascitis in meigs syndrome resolves after resection of the tumour. The etiology of ascitis is poorly understood.
Medline search reveals that ours is the third case reported of meigs syndrome in pregnancy. Novak M reported a similar case of "meigs syndrome with virilising ovarian fibrothecoma complicating pregnancy'. ${ }^{2}$ Also, a case of "sclerosing stromal tumour of the ovary associated with meigs syndrome and pregnancy' was reported by Gomes Salerhino DB. ${ }^{3}$ But in our case, not only a fibrothecoma was associated in one ovary, but also a large mucinous cystadenoma was present on the other side which led to the surgery of total hysterectomy with b/l salpingooophorectomy.

Review of literature shows that in 1954, meigs proposed limiting true meigs syndrome to benign and solid ovarian tumours accompanied by ascitis and pleural effusion, with the condition that removal of the tumour cures the patient without recurrence. Histologically, the benign ovarian tumour may be a fibroma, thecoma, cystadenoma or a granulosa cell tumour.

Pseudomeig syndrome consists of pleural effusion, ascitis and benign tumours of the ovary other than fibromas. These benign tumours include those of the fallopian tube or uterus or mature teratomas,struma ovarii or ovarian leiomyomas. ${ }^{4}$

Surgical treatment includes unilateral salpingooophorectomy to total hysterectomy with b/l salpingooophorectomy depending upon age and parity of the patient and whether the tumour is $\mathrm{u} / \mathrm{l}$ or $\mathrm{b} / \mathrm{l}$.

\section{CONCLUSION}

MEIG"S syndrome should always be kept in mind while dealing with a woman with ascitis especially if associated with pleural effusion and evidence of ovarian mass.

\section{Funding: No funding sources \\ Conflict of interest: None declared \\ Ethical approval: Not required}

\section{REFERENCES}

1. Padubidri, Daftary. Shaws Textbook of Gynaecology, 15e Elseviour India; 2014:385. ISBN9788131225486.

2. Novak M. Neuro Endocrinal lelt. 2009;30(2);192-4.

3. Gomes Salirhino DB. Rev Bras Ginecol Obstet. 2013;35(7):331-5.

4. Dunn JS, Anderson CD, Method MW. Hydropic degenerating leiomyoma presenting as a pseudo meigs syndrome with elevated CA-125. Obstet Gynecol. 1998;92:648-9.

Cite this article as: Gupta V, Sachan N. A rare case of Meigs syndrome in pregnancy with bilateral ovarian masses. Int J Reprod Contracept Obstet Gynecol 2016;5:4491-2. 